\title{
Pneumatosis cystoides intestinalis: a case report
}

\author{
Neumatosis quística intestinal: reporte de un caso \\ Juan J. Sánchez-Rodríguez*, Ana C. Utrillas-Martínez, Joana San Antón-Beranoaguirre, \\ Alberto A. Moreno-Olivieri and José M. Del Val-Gil \\ Department of General Surgery and Digestive Diseases, Hospital Obispo Polanco, Teruel, Spain
}

\begin{abstract}
Background: Pneumatosis cystoides intestinalis is an infrequent condition, characterized by the formation of gaseous content cysts under the mucosa and intestinal serous. Clinical case: 84-year-old woman, with a history of rheumatoid arthritis under immunosuppressive treatment, operated 2 years ago by pneumoperitoneum, where she was diagnosed of jejunal diverticulosis and mesenteric emphysema, with diffuse abdominal pain of 2 days of evolution, without other symptoms. In abdominal radiography: pneumoperitoneum with elevation of right hemidiaphragm and distention of small intestine. Given the suspicion of perforation of the intestinal wall, surgical intervention was decided, in which the patient was diagnosed with pneumatosis cystoides intestinalis. Conclusion: Pneumatosis cystoides intestinalis has an unknown etiology, although in a high percentage of patients it has been associated with obstructive pulmonary pathologies, connective tissue diseases, immunosuppression or gastrointestinal diseases. It is located more frequently in the colon and small intestine. It is diagnosed mainly through imaging tests (radiography or computed tomography). The treatment is conservative, performing surgical intervention if there is suspicion of intestinal necrosis; being difficult the differential diagnosis with a pneumoperitoneum by perforation of hollow viscera.
\end{abstract}

KEY WORDS: Pneumatosis cystoides intestinalis. Pneumoperitoneum. Intestinal wall.

\section{Resumen}

Antecedentes: La neumatosis quística intestinal es una condición infrecuente, caracterizada por la formación de quistes de contenido gaseoso debajo de la mucosa y la serosa intestinales. Caso clínico: Mujer de 84 años, con antecedente de artritis reumatoide en tratamiento inmunosupresor, intervenida hace 2 años por neumoperitoneo, con diagnóstico de diverticulosis yeyunal y enfisema mesentérico, acude con cuadro de dolor abdominal difuso de 2 días de evolución, sin otra sintomatología. En la radiografía de abdomen se observa neumoperitoneo con elevación del hemidiafragma derecho y distensión de asas del intestino delgado. Ante la sospecha de perforación de víscera hueca se decide intervención quirúrgica, en la cual se diagnostica a la paciente de neumatosis quística intestinal. Conclusión: La neumatosis quística intestinal es de causa desconocida, aunque en un elevado porcentaje de pacientes se ha visto asociada a enfermedades pulmonares obstructivas, enfermedades del tejido conectivo, inmunosupresión o enfermedades gastrointestinales. Se localiza más frecuentemente en el colon y el intestino delgado. Se diagnostica principalmente mediante pruebas de imagen (radiografía o tomografía computarizada). El tratamiento es conservador, realizándose intervención quirúrgica si existe sospecha de necrosis intestinal. Es difícil el diagnóstico diferencial con un neumoperitoneo por perforación de víscera hueca.

PALABRAS CLAVE: Neumatosis quística intestinal. Neumoperitoneo. Pared intestinal.

\footnotetext{
Correspondence:

*Juan J. Sánchez-Rodríguez Jaca, bloque 12, puerta 12, C.P. 44002, Teruel, España E-mail: juanjosr26@ hotmail.com
}

Cir Cir. 2018;86:329-332

Contents available at PubMed www.cirugiaycirujanos.com 


\section{Introduction}

Pneumatosis cystoides intestinalis $(\mathrm{PCl})$ is a rare condition that is characterized by the presence of gas in the intestinal wall, in the form of submucosal or subserous cysts ${ }^{1,2}$. Differential diagnosis mainly includes visceral perforation, since up to $30 \%$ of patients have pneumoperitoneum ${ }^{2}$. Herein, we present a clinical case of $\mathrm{PCl}$ and a literature review.

\section{Clinical case}

Eighty-four-year-old woman with a history of nonsteroidal anti-inflammatory drug gastropathy, rheumatoid arthritis under treatment with monoclonal antibodies and hypothyroidism. She had been intervened 2 years prior for pneumoperitoneum, with jejunal diverticulosis and emphysema of the mesentery, without macroscopic perforation, being found. She had had a laparoscopic cholecystectomy performed 5 months prior. The patient attended the emergency department with a 2-day history of diffuse abdominal pain, without fever, vomiting or changes in bowel habits.

On physical examination, she presented a distended abdomen, with pain in the lower portion, tympanism, uncomplicated midline laparotomy-related eventration, increased peristalsis and voluntary guarding to palpation in both iliac fossae.

Laboratory tests showed slight leukocytosis as the only significant finding. On abdominal X-ray, an image of pneumoperitoneum with elevation of the right hemidiaphragm and small bowel loops distension was observed (Fig. 1).

Emergency surgery by supraumbilical midline laparotomy was decided. Jejunal diverticulosis was observed from the angle of Treitz, with large diverticula (the largest, at about 5-6 cm from the fixed loop, had a diameter of about $4-5 \mathrm{~cm}$, with emphysema) and segmental pneumatosis of the mesojejunum, with no perforation being appreciated. In the terminal ileum, a pale-colored, millimetric nodule was observed and biopsied. The cavity was explored, with no evidence of perforation (Figs. 2 and 3).

In view of these findings, the $\mathrm{PCl}$ diagnosis was proposed.

\section{Results}

Evolution was favorable after the intervention, with analgesic and antibiotic treatment and bowel rest.

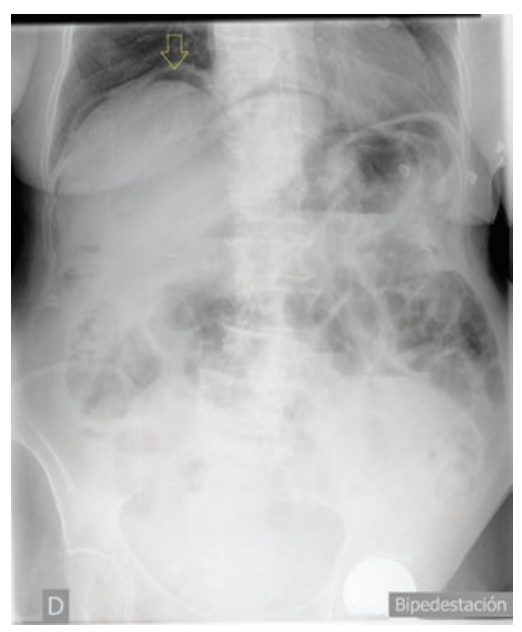

Figure 1. Abdominal X-ray in standing position showing left hemidiaphragm elevation due to pneumoperitoneum (arrow).

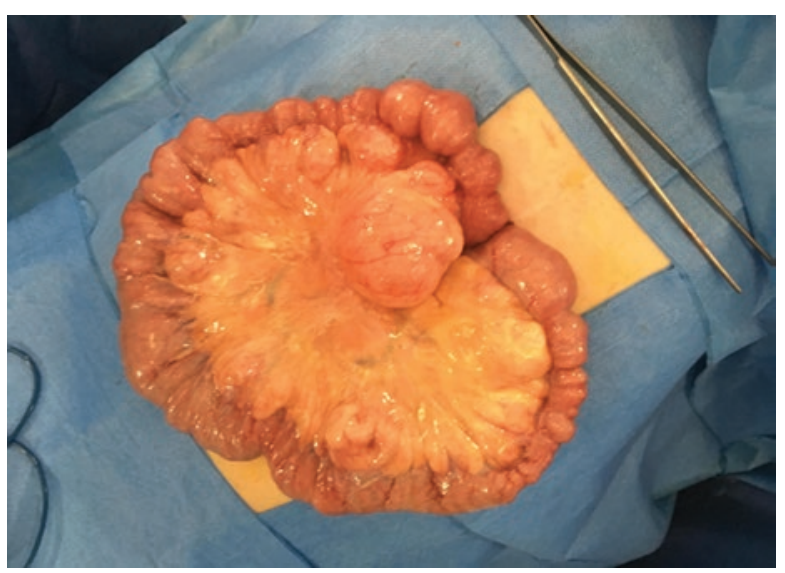

Figure 2. Pneumatosis cystoides intestinalis at the level of the mesojejunum.

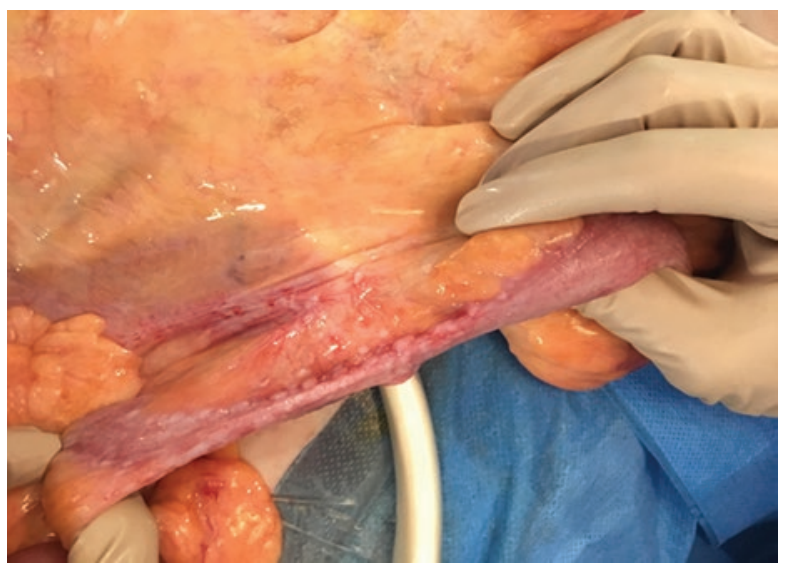

Figure 3. Pneumatosis cystoides intestinalis in the jejunal wall.

After 10 days, there was remission of clinical signs and symptoms, and the patient was discharged, with follow-up in the general surgery outpatient clinic. The terminal ileum biopsy result was reported as hyalinized fibrous tissue in the mesoileum. 


\section{Discussion}

$\mathrm{PCl}$ is a rare condition in which gas-containing cysts are formed beneath the intestinal mucosa and serosa and that has an unknown origin ${ }^{2-4}$. It is a pathology that mainly affects men, with a ratio of $3.5: 1$ with respect to women 4 .

In approximately $85 \%$ of patients, $\mathrm{PCl}$ is associated with chronic lung pathology, connective tissue conditions, immunosuppression or gastrointestinal diseases, and is classified as secondary PCl; the remaining $15 \%$ has no underlying pathology, with its etiology being idiopathic, thus being classified as primary $\mathrm{PCl}^{2,5}$.

$\mathrm{PCl}$ most common location is in the colon $(47 \%)$, followed by the small intestine (27\%), the stomach $(5 \%)$, and the colon and small intestine concurrently $(7 \%)^{6}$.

Several theories have been proposed to explain $\mathrm{PCl}$ pathogenesis ${ }^{2,6,7}: 1$ ) the mechanical theory; 2) the bacterial theory; 3) the pulmonary theory; and 4) the chemical theory. The mechanical theory suggests that there is air insufflation through the damaged intestinal mucosa, which may be caused by intestinal obstruction, severe constipation, gastrointestinal ulcers or intestinal necrosis, with an increase in intestinal pressure being produced. The bacterial theory proposes that there is an invasion of gas-producing bacteria, such as Clostridium spp., in the intestinal submucosa, which causes an accumulation of gases in the gastrointestinal wall. The pulmonary theory suggests that gas insufflation occurs in the peritoneal cavity, the mesentery and intestinal walls through the mediastinum, originating in alveolar damage due to an intrathoracic pressure increase caused by conditions such as chronic obstructive pulmonary disease and chronic cough. The chemical theory proposes that the cause is occupational, due to continuous exposure to trichloroethylene. In addition, the use of several drugs, such as alpha-glucosidase inhibitors, antipsychotics such as risperidone or immunosuppressive drugs is implicated as a cause of $\mathrm{PCl}$ by producing intestinal dilation and paralytic ileus. The patient of our clinical case is on treatment with monoclonal antibodies owing to her rheumatic disease, which could be the cause of her intestinal cystic pathology $y^{5,7}$.

The main clinical manifestations are gastrointestinal symptoms, including vomiting and abdominal distention in patients with $\mathrm{PCl}$ in the small intestine walls, and diarrhea with or without melena in those with $\mathrm{PCl}$ in the large intestine walls ${ }^{2,5,7}$. In the presented clinical case, abdominal distention is observed, according to the jejunal involvement shown by the patient. In most of patients, physical examination does not reveal signs of peritoneal irritation or abdominal guarding.

$\mathrm{PCl}$ diagnosis is mainly established by imaging tests (radiography or computed tomography) ${ }^{3}$. An abdominal $X$-ray can show numerous small gas-containing cysts that line up with the intestinal walls. The CT scan shows numerous gaseous cysts within the intestinal walls. These cysts can be described as linear, circular or with bubbles, although this is not correlated with the severity of the pathology. $\mathrm{PCl}$ can be accompanied by pneumoperitoneum ${ }^{4,6,7}$, which occurs in approximately $15 \%$ of cases where there is small intestine walls involvement, and in $2 \%$ when there is large intestine involvement. The patient of the described clinical case had pneumoperitoneum, which was observed on the chest x-ray as an elevation of the right hemidiaphragm (Fig. 1).

$\mathrm{PCl}$ is conservatively treated, regardless of the presence of pneumoperitoneum or gas at the level of the portal vein, unless there is evidence of bleeding or intestinal stenosis ${ }^{2,6}$. In the first place, for conservative treatment to be indicated, we must have a high diagnostic suspicion that we are dealing with this condition. Surgical treatment is carried out if clinical manifestations of intestinal necrosis appear. To conservatively treat pneumoperitoneum, the following conditions should be present: 1) absence of high fever; 2) abdominal pain spontaneous resolution; 3) possibility of intestinal pressure decompression; and 4) apparent presence of $\mathrm{PCl}$ (even if it is localized). All these conditions may suggest an absence of intestinal necrosis.

The patient in our clinical case required emergency surgical intervention to investigate the cause of pneumoperitoneum, with segmental pneumatosis being found at the mesojejunum level and emphysematous diverticulosis, with no intestinal perforation or necrosis being observed. Exploratory laparotomy was effective for decreasing intra-abdominal pressure and, subsequently, the patient evolved favorably with analgesic treatment, bowel rest and antibiotic therapy.

As a conservative treatment for $\mathrm{PCl}$, high-flow oxygen therapy can be effective ${ }^{2,6}$. Oxygen administration can help replace the nitrogen in intestinal pneumatosis, thus disappearing the pneumatosis by concentration gradients. In addition, oxygen can also help to suppress the growth of anaerobic bacteria, another of the possible causes of $\mathrm{PCl}$.

\section{Conclusion}

$\mathrm{PCl}$ is a rare pathology that in a few cases occurs with pneumoperitoneum. In the presence of 
pneumoperitoneum on imaging tests, we should suspect hollow viscus perforation. However, there are other causes associated with pneumoperitoneum. Therefore, practitioners should consider $\mathrm{PCl}$ as one of the differential diagnoses in the presence of pneumoperitoneum with no signs of peritoneal irritation or systemic manifestations, so that it can be conservatively treated and thus avoid surgical interventions.

\section{Conflicts of interest}

The authors declare not having any conflict of interests.

\section{References}

1. Beall D. Pneumatosis intestinalis: a review. Radiology. 1996;199:702.

2. Brun A. Pneumatosis cystoides intestinalis. Acta Pathol Microbiol Scand. 2009;53:243-52

3. Kunishi Y, Ota M, Kato Y, Maeda S. Pneumatosis cystoides intestinalis: lung window setting on CT. Clin Case Rep. 2017;5:1896-7.

4. Ooi SM. Pneumoperitoneum in a non-acute abdomen-pneumatosis cystoides intestinalis. Surg Case Rep. 2015;1:44.

5. Wada K, Takeuchi N, Emori M, Takada M, Nomura Y, Otsuka A. Two cases of pneumatosis cystoides intestinalis with intraperitoneal free air. Gastroenterol Res. 2017;10:208-11.

6. Wu LL, Yang YS, Dou Y, Liu QS. A systematic analysis of pneumatosis cystoides intestinalis. World J Gastroenterol. 2013;19:4973-8.

7. Pacheco Llerena R, Galindo Gómez J, Luna Valdez C, González Uzieda L, Fernández Hinojosa R, Mendieta Ampuero J, et al. Neumatosis quística intestinal: a propósito de un caso. Rev Soc Bol Ped. 2004;43: 15-7. 